\title{
Native and Nonnative Fish Populations of the Colorado River are Food Limited-Evidence from New Food Web Analyses
}

\begin{abstract}
ish populations in the Colorado
River downstream from Glen

Canyon Dam appear to be limited by the availability of high-quality invertebrate prey. Midge and blackfly production is low and nonnative rainbow trout in Glen Canyon and native fishes in Grand Canyon consume virtually all of the midge and blackfly biomass that is produced annually. In Glen Canyon, the invertebrate assemblage is dominated by nonnative New Zealand mudsnails, the food web has a simple structure, and transfers of energy from the base of the web (algae) to the top of the web (rainbow trout) are inefficient. The food webs in Grand Canyon are more complex relative to Glen Canyon, because, on average, each species in the web is involved in more interactions and feeding connections. Based on theory and on studies from other ecosystems, the structure and organization of Grand Canyon food webs should make them more stable and less susceptible to large changes following perturbations of the flow regime relative to food webs in Glen Canyon. In support of this hypothesis, Grand Canyon food webs were much less affected by a 2008 controlled flood relative to the food web in Glen Canyon.
\end{abstract}

\section{Background}

Between Glen Canyon Dam and Lake Mead, the Colorado River flows through Glen Canyon, Marble Canyon, and Grand Canyon. Immediately downstream from the dam in Glen Canyon, the Colorado River is characterized by cold water and almost no suspended sediment, whereas Marble and Grand Canyons are progressively warmer and more sediment laden (fig. 1).

Food is a resource that often limits the distribution or abundance of animal populations. In streams and rivers, aquatic invertebrates are an important food resource for fish populations. Thus, to identify the likely causes of Colorado River fish population response to adaptive management experimentation, it is critical

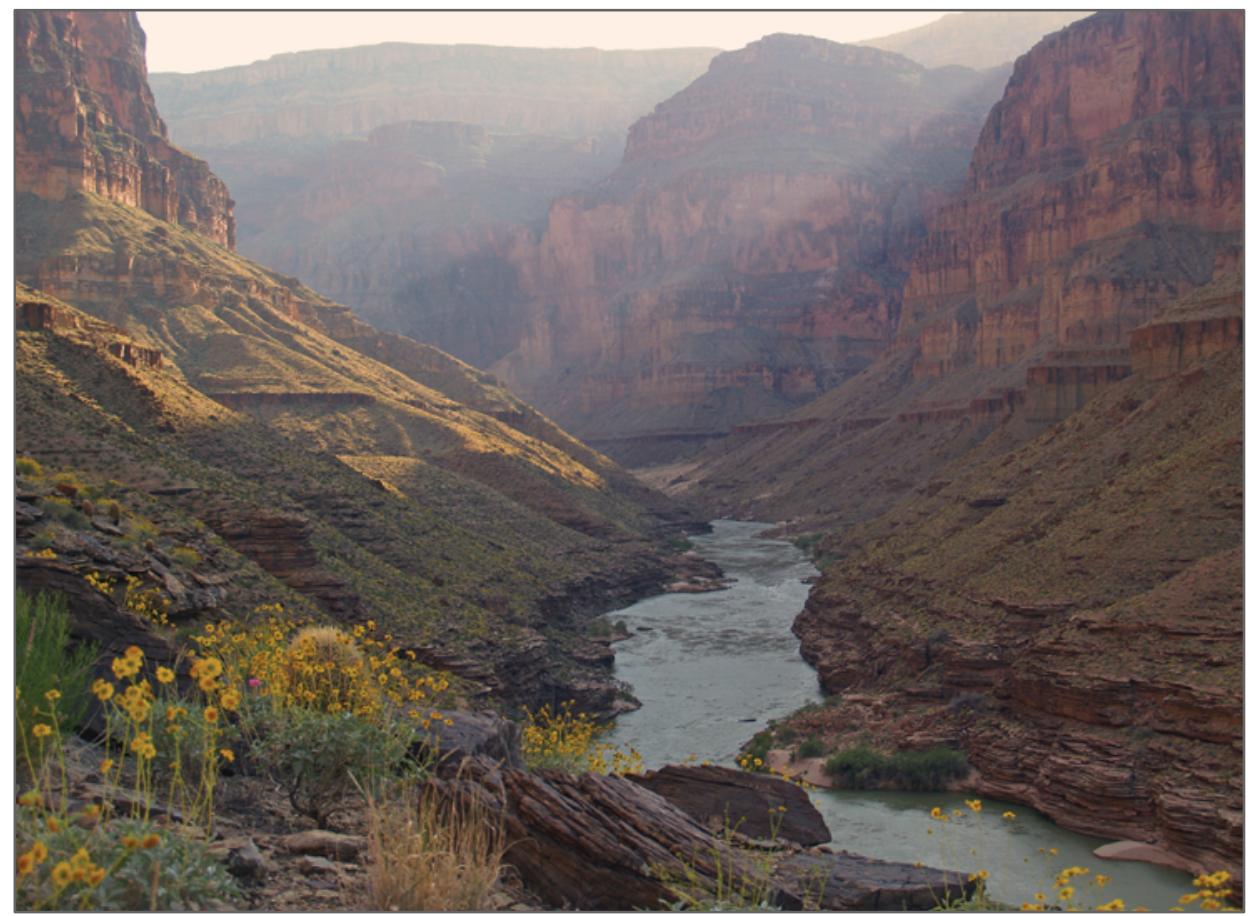

As one of the most carefully managed river systems in the world, the aquatic ecosystem of the Colorado River in the Grand Canyon has been heavily influenced by Glen Canyon Dam and the decades of controlled release of water for power generation. Photo by Robert 0 . Hall, Jr., used with permission.

to also describe responses by invertebrate prey resources. Food webs depict the flow of energy through an ecosystem by mapping who eats whom and in what quantity and, as such, they are a useful tool for investigating fundamental biological linkages in the Colorado River.

Food webs can be quantified by expressing all components of the web in a common currency: biomass produced and biomass consumed. Invertebrate production, for example, is the creation of new invertebrate biomass over time, and describes how much energy is available for consumption by fish. When conditions are favorable for invertebrates, their biomass and growth rates increase, and production estimates integrate both of these changes into a single metric. Because we wanted to resolve the degree to which fish populations in the Colorado River were food limited, we estimated consumption of invertebrates by fish in the same measurement units - biomass consumed. Thus, we could directly compare estimates of invertebrate production with estimates of invertebrate consumption by fish to understand the efficiency of energy transfer within the food web. Fish consumption was calculated from measurements of the food contents in the stomachs of fish, and annual consumption estimates were developed using bioenergetics modeling. Here, we summarize the results of our food web analyses, which were conducted between 2006 and 2009 and were recently reported in the peer-reviewed literature.

\section{Previous Research}

Early research on food webs in Glen, Marble, and Grand Canyons described spatial and temporal trends in the dominant species of algae and invertebrates.

Other studies linked those trends to characteristics of the nonnative rainbow trout (Oncorhynchus mykiss) population in Glen Canyon. However, those studies did not evaluate the response of the food web to significant management actions such as controlled flood releases, administratively referred to as high flow experiments. Although the feeding habits of nonnative 
Figure 1. Species

contributing to fish and invertebrate production change with distance downstream from Glen Canyon Dam, as shown by the pie charts for six sampling sites in Glen, Marble, and Grand Canyons. Total production (shown in the graph) also changes with distance downstream and is related to the sediment load (turbidity) of the water. Sediment load increases seasonally due to flood-derived inputs from key tributaries including the Paria River, Little Colorado River, and Kanab Creek. Error bars on graph represent the 95-percent confidence interval of the average production estimate; where bars are not shown, errors are smaller than size of data point. AFDM stands for "ash-free dry mass," a measure of the biological production exclusive of inorganic material such as bones and shells; it is given in units of grams AFDM per square meter per year. RM, river mile.

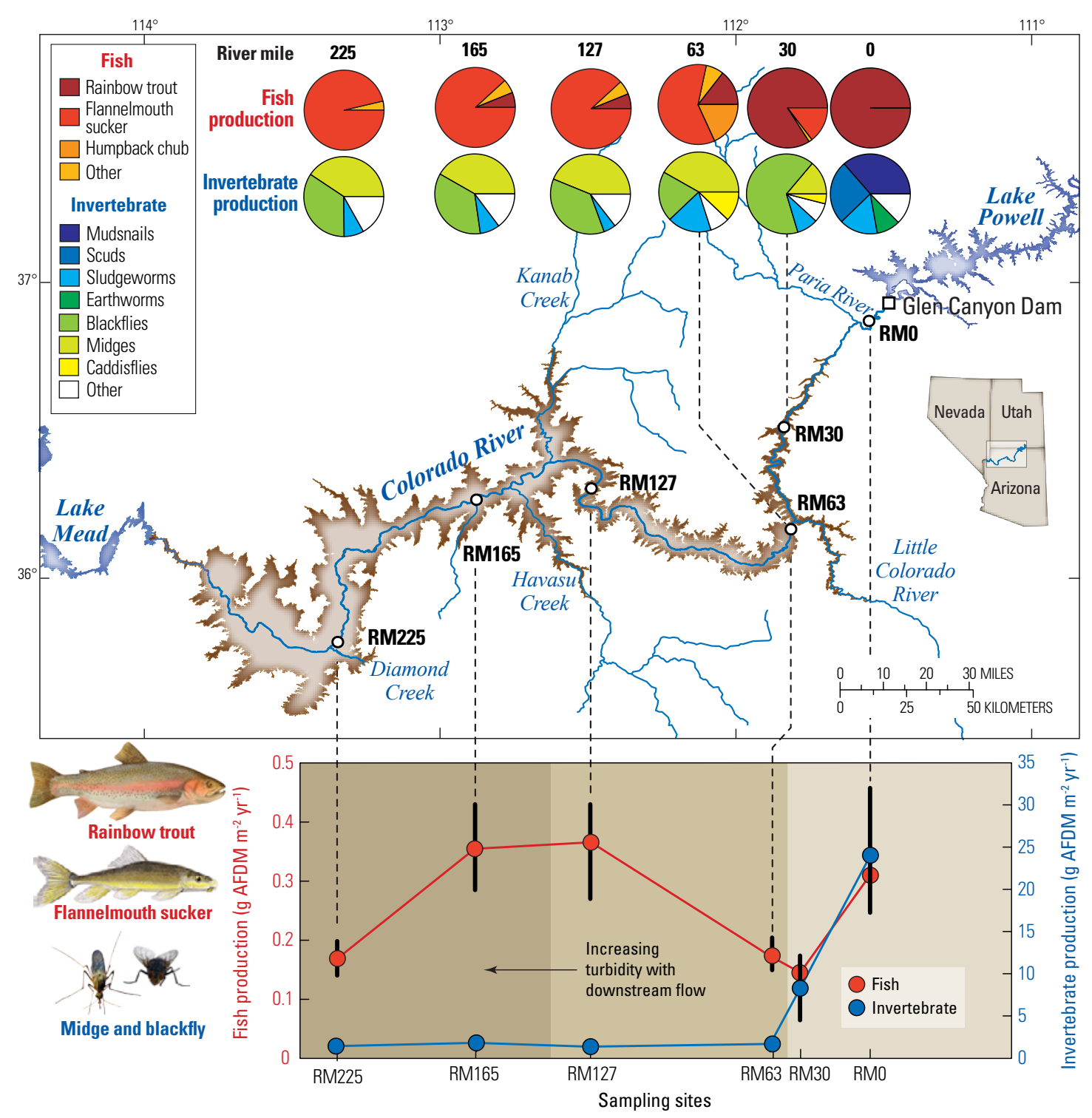

70 percent of invertebrate production there, but none of the invertebrates consume the large beds of algae that dominate riverbottom habitats (Wellard Kelly and others, 2013); thus, there is a large surplus and net export of filamentous algae from this segment of the river. Although invertebrate production in Glen Canyon is high, the most productive species are not important food items for rainbow trout, which constitute 95 percent of total fish production in this segment of the river (fig. 1). Nonnative New Zealand mudsnails (Potamopyrgus antipodarum) constituted nearly half of the available invertebrate production prior to the 2008 controlled flood, and this species of invertebrate cannot be effectively digested by rainbow trout (Cross and others, 2010; Cross and others, 2011). Blackflies (Family Simuliidae) and midges (Family Chironomidae) supported more than half of rainbow trout production in Glen Canyon. Although these insects represent only 1 to 10 percent of total invertebrate production, they are among the few prey species in Glen Canyon readily available to rainbow trout. The 2008 controlled flood caused a 60 percent decline in overall invertebrate production that was driven by a large reduction in the production of mudsnails (Cross and others, 2011). However, the production of midges and blackflies increased by 30 and 200 percent, respectively, in the year following the controlled flood, and these insects supported a 200 percent increase in rainbow trout production (Cross and others, 2011).

Algae production decreases from Glen to Marble Canyon and is even lower in Grand Canyon (Hall and others, 2010), because the higher suspended sediment load reduces light availability. Invertebrate production also decreases downstream from Glen Canyon, because the snails and scuds that dominate production in Glen Canyon are rare downstream (Cross and others, in press). Midges and blackflies dominate invertebrate production in Marble and Grand Canyons (fig. 1), and cobble bars are "hotspots" for midge 
and blackfly production. Production of these two insects in cobble bars is $2-10$ times higher than in other habitat types. Humpback chub are abundant immediately downstream from the Little Colorado River, constituting around 20 percent of total fish production; however, flannelmouth suckers (Catostomus latipinnis), which are omnivores and consume invertebrates, algae, and detritus (Zahn-Seegert, 2010; Donner, 2011), represent 95 percent of fish production at reaches farther downstream (fig. 1).

Food web analyses also indicate that native fish production and distribution in Grand Canyon may be limited by the availability of high-quality invertebrate prey such as midges and blackflies because native fishes in Grand Canyon consume nearly all of the available midge and blackfly production annually. However, total fish production does not appreciably change with distance downstream from Glen Canyon Dam (fig. 1), because native fishes also make use of noninvertebrate foods such as algae and detritus (Cross and others, in press).

The food webs in Grand Canyon are more complex relative to Glen Canyon because each species in the web is involved in more feeding connections (fig. 2). Based on theory and studies from other ecosystems, all of these attributescomplexity, incorporation of detritus into the web, and dominance by omnivoresindicate that Grand Canyon food webs should be more stable and less susceptible to large changes following perturbations of the flow regime than is the case in Glen Canyon; in support of this hypothesis, Grand Canyon food webs were much less affected by the 2008 controlled flood relative to the food web in Glen Canyon (Cross and others, in press; Rosi-Marshall and others, 2010).

\section{Management Implications}

These food-web studies help inform management of the Colorado River ecosystem by identifying the likely causes of fish-population response to adaptive management experimentation. In the absence of controlled floods, the invertebrate assemblage in Glen Canyon would likely be dominated by nonnative New Zealand mudsnails that do not sustain the rainbow trout fishery. Our studies indicate that future controlled floods should favor insects such as midges and blackflies that are important prey for rainbow trout (Cross and others, 2011). The direct effects of controlled floods released from Glen Canyon Dam on food webs and invertebrate populations further downstream in Marble and Grand Canyons appear minimal; however, floods may indirectly affect food webs in Marble
Canyon, because the large cohorts of rainbow trout produced in Glen Canyon migrate downstream and prey upon humpback chub and other native fish.

Low invertebrate production in the Colorado River may be responsible for several undesirable food web properties. The low availability of invertebrate prey likely limits the growth of large rainbow trout. Low invertebrate production may also limit the abundance and distribution of humpback chub and may be responsible for the dominance of flannelmouth suckers in the native fish assemblage, because flannelmouth suckers can make efficient use of low-quality food items (algae and detritus) that are not accessible to humpback chub. Low invertebrate production in Grand Canyon may also limit the success of efforts to reintroduce native fishes that have been extirpated from Grand Canyon, such as the razorback sucker (Xyrauchen texanus) and Colorado pikeminnow (Ptychocheilus lucius).

An investment portfolio of stocks is a useful metaphor for the food web; an ideal investment portfolio is one that contains a diversity of stocks that can grow the account over variable economic conditions. Similarly, riverine food webs tend to be most efficient and productive when there is a variety of invertebrate prey resources available such that fish growth and production can occur over variable

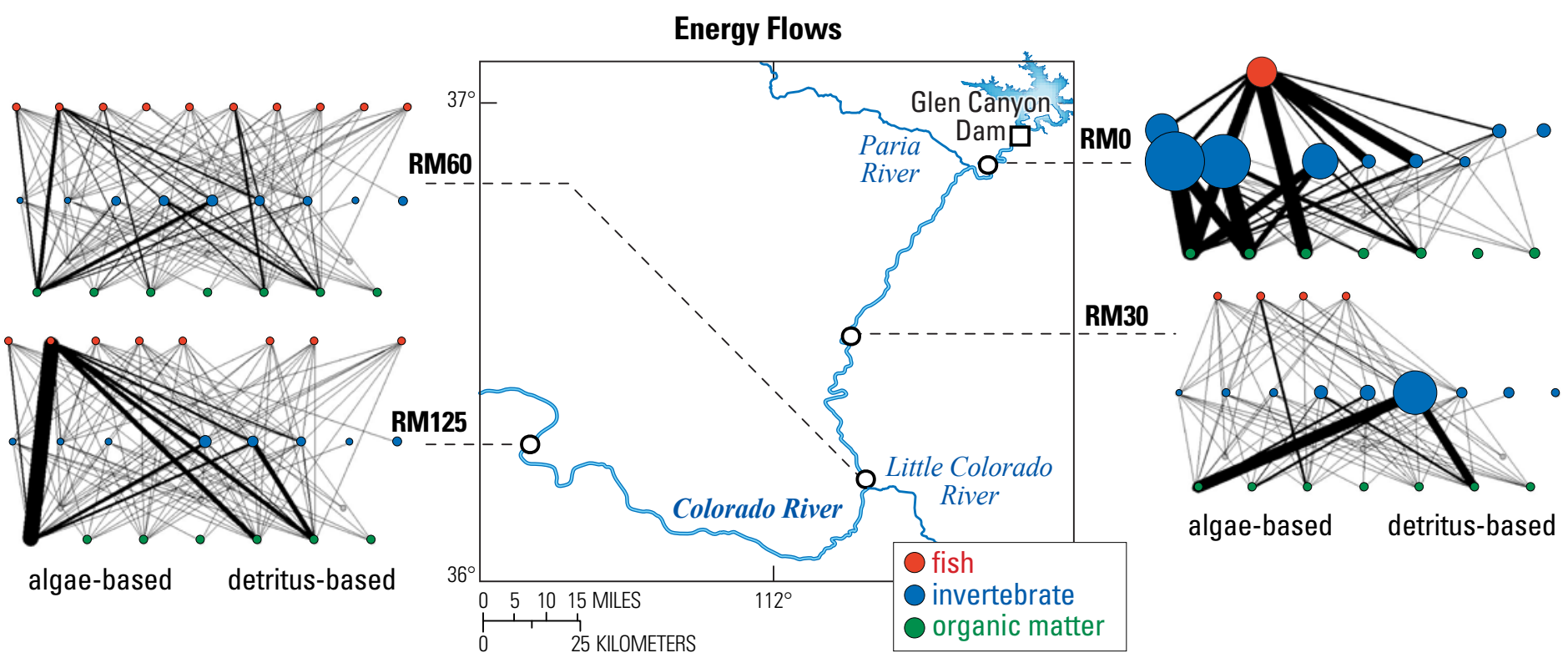

Figure 2. Food web diagrams depicting consumption by invertebrates and fish in the Colorado River through Glen Canyon and Grand Canyon. Line widths correspond to the magnitude of consumption. Food web complexity, or the number of connections in a web, increases with distance from Glen Canyon Dam for two main reasons: (1) there are more species of fish in downstream assemblages (see top row of interactions in each panel) and (2) invertebrates are consuming both algae-based and detritus-based resources at downstream sites (bottom row of interactions in each panel). Because biomass consumption by fishes was much lower in magnitude than by invertebrates, consumption by fishes in Glen Canyon was multiplied by 50 , and consumption by fish in Grand Canyon was multiplied by 5 , for purposes of visualization. RM, river mile. 
environmental conditions. Because the portfolio of invertebrate "stocks" in the Colorado River is extremely limited relative to unregulated rivers, the overall production of the Colorado River's investment portfolio of invertebrates is also limited, as is the production of the fish populations that depend on these invertebrates.

\section{Next Steps}

A current goal of the Glen Canyon Dam Adaptive Management Program (GCDAMP) is to manage food webs to support the biodiversity of native fish species, while limiting the negative effects of nonnative sport fish like rainbow trout. One of the benefits of describing food webs in detail is that key species interactions are identified; managers can use this information to alter the food web to achieve these management goals.

Fish eat most of the midge and blackfly biomass that is produced annually throughout Glen, Marble, and Grand Canyons. Thus, management actions that alter the production of these aquatic insects, such as controlled flood releases, could lead to changes in fish production; however, controlled flood releases only appear to increase midge, blackfly, and by extension, fish production in Glen Canyon. If increased native fish production is desired in Marble and Grand Canyons, other management actions could be considered. For example, hydroelectric power generation from Glen Canyon Dam causes large daily changes to the Colorado River's discharge and lowers algae production relative to more stable discharges (Robert Hall, Jr., and others, unpub. data, 2013). Thus, stabilizing the discharge regime could lead to increased algae production at downstream sites, which may in turn have positive effects on invertebrate and fish production.

The GCDAMP could also attempt to increase native fish production by increasing the number of species in the invertebrate assemblage, which is analogous to increasing the number of stocks in the investment portfolio. One option that may help achieve this goal is manipulation of the river's seasonal water temperature regime. Aquatic insects are very sensitive to temperature; for example, egg hatching and emergence of adult insects is often triggered by low and high temperature extremes, respectively. The water temperatures of the Colorado River downstream from Glen Canyon Dam lack strong seasonal variability, which may prevent successful colonization by native insects that historically lived in this river. River temperatures may be different in the future because of installation of a selective withdrawal structure that allows warmer surface water from Lake Powell to be released, experimental flow regimes that both maximize summer warming and winter cooling, or climate-driven changes in the temperature of water released from Lake Powell. Changes in the river's seasonal temperature regime may allow other regional invertebrate species to colonize the Colorado River. For example, many species of mayflies (Order Ephemeroptera) and caddisflies (Order Trichoptera) are abundant and productive in tributaries, but are conspicuously absent from Glen, Marble, and Grand Canyon. Concerns exist, however, that warmer water in Grand Canyon could inadvertently benefit nonnative warm-water fishes that may compete with or eat native fishes. If direct temperature manipulation is not an option, the GCDAMP could consider actively introducing native species of invertebrates that persist in other parts of the Colorado River that also have altered seasonal temperature regimes.

Regardless of the future direction of adaptive management experimentation in the Colorado River downstream from Glen Canyon Dam, food web investigations like those described here will help inform these experiments by identifying the causal pathways underlying changes in fish populations.

\section{References Cited}

Cross, W.F., Baxter, C.V., Donner, K.C., RosiMarshall, E.J., Kennedy, T.A., Hall, R.O., Jr., Wellard-Kelly, H.A., and Rogers, R.S., 2011, Ecosystem ecology meets adaptive management - food web response to a controlled flood on the Colorado River, Glen Canyon: Ecological Applications, v. 21, no. 6, p. 2016-2033, http://www.esajournals.org/doi/ abs/10.1890/10-1719.1

Cross, W.F., Baxter, C.V., Rosi-Marshall, E.J., Hall, R.O., Jr., Kennedy, T.A., Donner, K.C., Wellard Kelly, H.A., Seegert, S.E.Z., Behn, K., and Yard, M.D., in press, Foodweb dynamics in a large river discontinuum: Ecological Monographs (online), http://dx.doi.org/10.1890/12-1727.1.

Cross, W.F., Rosi-Marshall, E.J., Behn, K.E., Kennedy, T.A., Hall, R.O., Fuller, A.E., and Baxter, C.V., 2010, Invasion and production of New Zealand mud snails in the Colorado River, Glen Canyon: Biological Invasions, v. 12, no. 9, p. 3033-3043, doi: 10.1007/s10530-0109694-y, http://www.springerlink.com/content/ bv834031865h2077/.
Donner, K.C., 2011, Trophic basis of production of fishes in the Colorado River, Grand Canyonan assessment of potential competition for food: Pocatello, Idaho State University, M.S. thesis.

Hall, R.O., Jr., Kennedy, T.A., Rosi Marshall, E.J., Cross, W.F., Wellard, H.A., and Baxter, C.F., 2010, Aquatic production and carbon flow in the Colorado River, in Melis, T.S., Hamill, J.F., Bennett, G.E., Coggins, L.G., Jr., Grams, P.E., Kennedy, T.A., Kubly, D.M., and Ralston, B.E., eds., Proceedings of the Colorado River Basin Science and Resource Management Symposium, November 18-20, 2008, Scottsdale, Arizona: U.S. Geological Survey Scientific Investigations Report 2010-5135, 105-112 p., http://pubs.usgs. gov/sir/2010/5135/.

Wellard Kelly, H.A., Rosi-Marshall, E.J., Kennedy, T.A., Hall, R.O., Cross, W.F., and Baxter, C.V., 2013, Macroinvertebrate diets reflect longitudinal and seasonal changes in food availability downstream of a large dam: Freshwater Science, v. 32, no. 2, p. 397-410, http://dx.doi.org/10.1899/12-088.1.

Rosi-Marshall, E.J., Kennedy, T.A., Kincaid, D.W., Cross, W.F., Kelly, H.A.W., Behn. K.A., White, T., Hall, R.O., Jr., and Baxter, C.V., 2010, Short-term effects of the 2008 highflow experiment on macroinvertebrates in the Colorado River below Glen Canyon Dam, Arizona: U.S. Geological Survey Open-File Report 2010-1031, 28 p., http://pubs.usgs.gov/ of $/ 2010 / 1031 /$

Zahn-Seegert, S.E., 2010, Diet overlap and competition among native and non-native smallbodied fishes in the Colorado River, Grand Canyon, Arizona: Chicago, Loyola University, M.S. thesis, $70 \mathrm{p}$.

Theodore A. Kennedy ${ }^{l}$, Wyatt F. Cross ${ }^{2}$, Robert O. Hall, Jr. ${ }^{3}$, Colden V. Baxter ${ }^{4}$, and Emma J. Rosi-Marshall

${ }^{1}$ U.S. Geological Survey
${ }^{2}$ Montana State University
${ }^{3}$ University of Wyoming
${ }^{4}$ Idaho State University
${ }^{5}$ Cary Institute of Ecosystem Studies

Edited by Claire M. Landowski Graphic design by Jeanne S. DiLeo

For more information, contact: U.S. Geological Survey Southwest Biological Science Center, Grand Canyon Monitoring and Research Center, Flagstaff Arizona http://www.gcmrc.gov

This Fact Sheet and any updates to it are available online at:

http://pubs.usgs.gov/fs/2013/3039 